\title{
Bentuk dan Peran Kapital Sosial dalam Percepatan Penurunan Stunting di Desa Pandanwangi, Lombok Timur
}

\author{
Husnul Ma'ad ${ }^{1}$ dan Triyanti Anugrahini \\ Universitas Indonesia
}

\begin{abstract}
The Poor nutritional status of children under five years of age remains a major concern in Indonesia. Based on RISKESDAS (Basic Health Survey) 2018, NTB province was listed as one of the 10 provinces with the highest stunting rates in Indonesia with 33,49 children are stunted, and Lombok Timur district was the highest stunting in NTB with prevalence reached 43, $5 \%$. Considering the long-lasting effects of child malnutrition, the district government of Lombok Timur put stunting reduction program as a priority. In 2017, Pandanwangi village was selected as one pilot village for implementing the national strategy to accelerate stunting prevention and reduction. Pandanwangi village successfully implemented integrated approach dealing with stunting reduction through specific and sensitive nutrition intervention. The aim of the study was to identify the form and role of social capital on stunting reduction program activities in Pandanwangi village. This was a qualitative study on collecting information from informants the health and non-health sector. Data were collected through in-depth interviews, observation and focus group discussion. The results showed that several forms of social capital included in social bonding, bridging, linking and played a role in the acceleration of the decline in stunting. Based on the research results, each type of social capital plays an important role in creating a enabling environment in stunting reduction efforts. The results of the study also showed a synergy between various forms of social capital that allowed the community to accelerate stunting reduction in Pandanwangi Village
\end{abstract}

Keywords : Social Capital, Stunting Reduction, Social Welfare

\begin{abstract}
Abstrak
Status gizi yang buruk pada balita masih menjadi perhatian utama di Indonesia. Berdasarkan RISKESDAS (Riset Kesehatan Dasar) 2018, Provinsi NTB masuk dalam 10 provinsi dengan angka stunting tertinggi di Indonesia dengan 33,49\% balita stunting, dan Kabupaten Lombok Timur menjadi Kabupaten degan kasus stunting tertinggi di NTB dengan prevalensi mencapai 43, 5\%. Mempertimbangkan dampak jangka panjang dari malnutrisi pada anak, Pemerintah Kabupaten Lombok Timur menempatkan program pengurangan stunting sebagai prioritas. Pada tahun 2017, Desa Pandanwangi terpilih sebagai salah satu desa percontohan penerapan strategi nasional percepatan pencegahan dan pengurangan stunting. Desa Pandanwangi berhasil menerapkan pendekatan terpadu dalam penanggulangan stunting melalui intervensi gizi yang spesifik dan sensitif. Penelitian ini bertujuan untuk mengidentifikasi bentuk dan peran modal sosial dalam kegiatan program pengurangan stunting di Desa Pandanwangi. Penelitian ini merupakan penelitian kualitatif dengan mengumpulkan informasi dari informan bidang kesehatan dan non kesehatan. Pengumpulan data dilakukan melalui wawancara mendalam, observasi dan diskusi kelompok terfokus.
\end{abstract}

\footnotetext{
${ }^{1}$ maad04@yahoo.com
} 
Hasil penelitian menunjukkan bahwa beberapa bentuk kapital sosial yang termasuk dalam kapital sosial bonding, bridging, linking dan berperan dalam percepatan punurunan stunting. Berdasarkan hasil penelitan, masing-masing jenis kapital sosial berperan penting dalam menciptakan lingkungan pendukung dalam kegiatan pengurangan stunting. Hasil penelitian juga menunjukkan adanya sinergi antara berbagai bentuk kapital sosial yang memungkinkan masyarakat melakukan percepatan pengurangan stunting di Desa Pandanwangi

Kata Kunci : Kapital Sosial, Penurunan Stunting, Kesejahteraan Sosial

\section{Pendahuluan}

Desa Pandanwangi terletak di Kecamatan Jerowaru, Kabupaten Lombok Timur, NTB. Desa Pandanwangi merupakan desa yang memiliki angka stunting yang paling tinggi yang mencapai 268 anak. Namun berdasarkan hasil pendataan Puskesmas, angka anak stunting berhasil turun menjadi 118 anak atau turun 58,74\% (Puskesmas Jerowaru, 2019). Pemerintah desa dan masyarakat telah melakukan upaya-upaya strategis penurunan stunting melalui implementasi program-program spesifik seperti pemberian tablet tambah darah, pelaksanaan posyandu, pemantuan anak stunting dan penyuluhan kesehatan. Namun, inisiatif pembangunan pangan dan gizi, khususnya penanangan stunting banyak datang dari pemerintah pusat, provinsi dan kabupaten. Inisitaif yang muncul dari desa belum di angkat secara lebih strategis, padahal bisa langsung berhubungan dengan masyarakat dan bisa berkesinambungan.

Desa Pandanwangi, memiliki beberapa aspek kapital sosial dalam upaya penurunan stunting. Keterbatasan geografis membuat masyarakat Desa Pandanwangi melakukan berbagai inovasi dengan menggunakan kekuatan kapital sosial untuk bertahan dari keterbatasan yang ada. Dalam bidan pertanian, masyarakat berhasil adaptasi perubahan iklim melalui penggabungan tradisi lokal dan modern sebagai acuan dalam pertanian dan masih terpeliharanya tradisi embung sebagai teknik penangkapan air hujan untuk kepentingan pertanian. Dalam bidang sosial, masyarakat masih mempertahankan nilai-nilai adat dan agama dalam kehidupan sehari-hari. 
Ada berbagai definisi tentang Kapital Sosial. Christiaan Grootaert (1998), membagi definisi konsep kapital sosial menjadi tiga bagian. Pertama, konsep kapital sosial oleh Putnam sebagai kumpulan "horizontal association" antar masyarakat; kapital sosial terdiri dari jaringan-jaringan sosial ("jaringan keterlibatan masyarakat") dan norma-norma terkait yang memiliki dampak terhadap produktifitas masyarakat. Terdapat dua hal penting dalam definisi ini yaitu jaringan dan norma secara empirik saling terkait dan terdapat konsekuensi ekonomi dari keterkaitan tersebut. Kedua, definisi konsep yang lebih besar yang di paparkan oleh Colleman yang mengungkapkan bahwa kapital sosial sebagai variasi dari kesatuankesatuan yang berbeda yang mencakup adanya struktur sosial dan fasilitasi aksi dari actor-aktor tersebut. Ketiga, terkait membangun lingkungan yang kondusif untuk memampukan norma untuk memnguatkan struktur sosial melaui institusi dan struktur seperti aturan, pemerintahan, kelompok, dan lainnya.

Aiyar dalam Harris (2011) yang di kutip oleh Adi (Adi, 2013) mengemukakan tiga bentuk kapital sosial, yaitu: Bonding Capital yang merupakan kapital sosial yang mengikat anggota-anggota masyarakat dalam suatu kelompok tertentu, Bridging Capital yang merupakan salah satu bentuk kapital sosial yang menghubungkan warga masyarakat dari kelompok sosial yang berbeda dan Linking capital yang merupakan suatu ikatan antara kelompok warga masyarakat yang lemah dan kurang berdaya, dengan kelompok warga masyarakat yang lebih berdaya (powerfull people), misalnya bank, polisi, dinas pertanian dan sebagainya. Claridge (2018) menambahkan bahwa bonding menggambarkan hubungan dalam suatu kelompok atau komunitas yang ditandai dengan tingkat kesamaan yang tinggi dalam karakteristik demografis, sikap, dan informasi serta sumber daya yang tersedia. Kedua adalah bridging yaitu adalah ikatan kapital sosial yang lebih luas dan lebih longgar. Bridging, menurut Claridge (2018), merupakan kapital sosial yang menggambarkan koneksi yang menghubungkan orang-orang melintasi perbedaan yang biasanya memecah belah masyarakat (seperti ras, atau kelas, atau agama). Kapital sosial ini menjadi jembatan antara komunitas, kelompok, atau organisasi. Ketiga adalah linking, yaitu ikatan kapital sosial yang angggotanya dari beragam latar belakang, semisal satu komunitas dengan pihak luar, dan ikatan yang 
demikian akan memungkinkan kita bisa mengakses beragam sumber untuk kepentingan komunitas).

Peran kapital sosial dalam mempengaruhi status kesehatan secara menyeluruh di di jelaskan oleh Galab et all (Galab, et all, 2006). Galab (2006) menyebutkan ada empat jalur potensi pengaruh kesehatan individu. Pertama, mempengaruhi perilaku kesehatan melalui penyebaran informasi kesehatan yang efektif, kedua, meningkatkan kemungkinan adopsi perilaku kesehatan yang positif, ketiga, meningkatkan akses ke layanan kesehatan setempat dan fasilitas lainnya, dan terakhir melalui proses psikososial, misalnya penyediaan dukungan emosional.

Peran kapital sosial dan pengaruhnya terhadap kesehatan dijabarkan secara lebih detail oleh Eriksson (2011). Eriksson mengkaitkan modal sosial individu dan kolektif dan hubungan nya terhadap kesehatan. Erikson melihat terkaitan antara sumber kapital sosial dengan struktur makropolitik dan karakteristik jaringan, baik kapital sosial yang di miliki oleh individu maupun secara kolektif. Pada tahapan indidu, kapital sosial berupa norma dan solidaritas dapat memunculkan adanya dukungan sosial (social support), adanya pengaruh sosial (social influence), adanya partisipasi social (social participation), dan memuncukan hubungan timbal balik terkait sumberdaya material. Norma yang diinternalisasi membuat orang berkewajiban dan bersedia untuk 'berperilaku benar', seperti mendukung orang lain. Selain itu, solidaritas bisa membuat orang mau membantu sesama. Selanjutnya, dukungan sosial secara positif mempengaruhi kesehatan yang memungkinkan individu untuk mengakses berbagai bentuk dukungan. Norma dan solidaritas juga dapat mempengaruhi kesehatan melalui pengaruh sosial antar anggota jaringan. Orang yang dipercaya seperti tokoh masyarakat, champion yang ada di sekitar tempat tinggal individu, dan ataupun anggota keluarga yang memiliki pengetahuan lebih, dapat memengaruhi perilaku kesehatan orang lain dengan berfungsi sebagai panutan. Pengaruh ini dapat meningkatkan kesehatan atau merusak kesehatan tergantung pada norma yang ada di jaringan. Norma dan solidaritas yang kuat juga dapat mengarah pada kontrol sosial yang tinggi, yang memungkinkan jaringan untuk mengontrol kepatuhan norma. Mereka yang mengikuti norma dihargai 
dengan status. Tulisan ini akan membahas bentuk dan peran kapital sosial dalam percepatan penurunan stunting.

\section{Metode Penelitian}

Penelitian ini menggunakan metode kualitatif. Pengumpulan data dilakukan melalui observasi, wawancara mendalam, pengumulan dokumen pendukung dan focus group discussion dengan pemerintahan desa, tokoh -tokoh agama dan adat, perwakillan kelompok, dan masyarakat . Hasil wawancara kemudian dianalisis secara deskriptif kualitatif dan dilengkapi dengan data hasil observasi dan data document terkait.

\section{Hasil dan Pembahasan}

\section{Bonding Kapital Sosial dalam penurunan stunting}

Bonding kapital sosial di Desa Pandanwangi terdapat dalam nilai-nilai yang masih di pegang teguh dan masih terus di praktekan dalam kehidupan sehari-hari, yaitu nilai-nilai gotong royong, budaya malu dan nilai. Budaya gotong royong dan saling membantu tercermin dalam kegiatan Betanje dan Babarayan. Kegiatan betanje, merupakan tindakan pro-aktif dari masyarakat yang memiliki kelebihan baik sumber daya maupun informasi, dan membagikannya kepada individu lain yang ada di lingkaran terdekatnya. Fokus utama biasanya di lakukan kepada keluarga dekat, dan selanjutnya ke tetangga sekitar rumah. Pada tingkatan yang lebih luas, akan di bagikan kepada masyarakat dari kelompok pra sejahtera yang ada di dusun maupun desa. Betanje di terapkan dalam berbagai kegiatan. Biasanya betenje sering digabungkan dalam acara adat dan keagaamaan. Pada saat kegiatan kegaamaan, ibuibu akan masak bersama dan hasil masakan kemudian akan di makan bersama pada saat acara. Setiap setiap orang yang hadir akan mendapat bagian yang bisa di bawa pulang berisi nasi dan lauk pauk untuk keluarga, dan jajanan bagi anak-anak. Betanje juga dilakukan dengan mengantar makanan langsung ke rumah orang yang yang membutuhkan, terutama untuk tetangga sekitar rumah untuk mempererat jalinan antar tentangga dan bentuk kepedulian masyarakat. Betanje juga bisa dilakukan untuk hasil pertanian. Pemilik lahan yang memiliki hasil panaen yang 
bagus, akan berbagai kepada keluarga dekatnya. Tidak hanya itu, mereka juga akan memberikan kepada orang lain di sekitar dusun yang membutuhkan pada saat setelah panen.

Babarayan merupakan budaya berbagai makanan bersama. Masyarakat desa membawa makanan sendiri, kemudian berkumpul di salah satu rumah warga, lalu mereka berbagi makanan yang di bawa. Untuk skala kecil, biasanya berbagai makanan antar keluaga yang berada sekitar rumah. Tiap rumah akan membawa makanan yang terbaik yang mereka memiliki, kemudian akan makan Bersama. Tradisi babarayan menunjukan kebersamaan antara warga, dan budaya gotong royong. Dalam skala kecil, menumbuhkan semangat untuk membantu masyarakat desa dan kepedulian terhadap tetangga sekitar. Penduduk desa yang miskin sangat terbantu dengan karena mendapatkan makanan bergizi yang diperoleh dari masyakarat yang berada. Melalui kegiatan makan bersama, masyarakat bisa mengetahui kondisi tetangganya, bertukar informasi, menciptakan trust antar tetangga.

Budaya malu masih dipegang teguh oleh masyarakat dan menjadi pemicu perubahan perilaku dan aksi untuk penurunan stunting. Keluarga yang memiliki anak stunting akan berusaha semaksimal mungkin untuk memberikan yang terbaik kepada anak melalui pemberian makanan bergizi dan beragam, pemberian makanan tambahan. Karena Desa Pandanwangi merupakan juga daerah yang tertinggi angka stunting nya di Kabupaten Lombok Timur, maka menciptakan kesadaran kolektif untuk pentingnya melakukan aksi untuk mengurangi angka stunting oleh seluruh stakeholder, baik individu, aparat pemerintahan, kelompok-kelompok yang ada di masyarakat dan juga tokoh agama dan tokoh adat.

Nilai agama masih menjadi nilai kuat yang terus di jalankan oleh masyarakat Desa Pandanwangi. Bagi masyarakat Desa Pandanwangi dan masyarakat di Kecamatan Jerowaru pada umummnya, tokoh agama yang disebut sebagai Tuan Guru memiliki status sosial dan memainkan peranan penting untuk semua aspek kehidupan. Peran Tuan Guru tidak hanya untuk urusan keagaamaan saja, namun juga menjadi panutan dalam menghadapi persoalan lainya seperti ekonomi, Pendidikan, dan pertanian, Salah satu Tuan Guru yang dihormati di Desa 
Pandanwangi mendirikan Yayasan Qudwatus Sholihin (YAQIN) yang berada di dusun Pemondah. Yaysasan YAQIN mendorong perbaikan Pendidikan dan ekonomi dengan ikut serta dalam kegiatan Pendidikan formal, penyelengaraan Pendidikan non formal melalui pondok pesentren, pengajian rutin melalui masjelis ta'lim dan mengadakan. Yayasan juga menjalankan aktifitas sosial melalui panti asuhan dan panti jompo. Selain itu, di dusun Pengangsing terdapat Madrasah Darul Mujahiddin Nahdatul Wathan. Setiap hari setelah selesai magrib memberikan ceramah kepada pemuda yang salah satunya adalah untuk meningkatkan pemahaman kesehatan bagi remaja. Setiap bulan ada pengajian bulanan. Pengajian yang ada di Dusun Pangangsing terhubung dengan Tuan Guru yang ada di Jerowaru. Selain itu kelompok pertemuan rutin keagamaan juga menjadi sarana untuk transformasi informasi antar warga di Desa Pandanwangi. Masyarakat rutin mengadakan hiziban dan yasinan. Kegiatan yasinan dan hiziban yang di lakukan seminggu sekali dan dilakukan secara bergiliran antar dusun. Pada saat acara ini pun terkadang penceramah membawakan tausiah atau pengajian yang beririsan dengan kesehatan baik itu ibu dan anak.

Landasan agama menjadi dorongan bagi prilaku sehat sesuai kepada yang di ajarkan oleh pemuka agama baik pada saat di pesantren maupun pada saat kegiatan agama yasinan dan hiziban. Keluarga yang ikut serta dalam kegiatan ini akan belajar prilaku hidup yang mendorong percepatan penurunan stunting seperti pencegahan perkawinan anak, kewajiban orang tua untuk memberikan makanan yang sehat dan bergizi kepada anaknya, dan kewajiban untuk tidak mewariskan generasi yang lemah.

Kearifan lokal juga menjadi bagian penting yang terus berjalan di Desa Pandanwangi. Masyarakat Desa Pandanwangi masih terus memelihara kearifan lokal berupa embung-embung yang berguna sebagai bagian untuk mempertahankan ketahanan pangan. Konsep embung merupakan bagian dari budaya kolektif masyarakat yang mengedepankan kebersamaan dan gotong royong. Masyararakat yang memiliki embung, akan berbagi hasil pertanian dan perikanan kepada kelompok masyarakat yang membutuhkan. Keberadaan embung juga dapat 
meningkatkan jaringan antara masyarakat, dan juga jaringan dengan masyarakat luar Desa Pandanwangi.

Salah satu kearifan lokal yang juga mendukung percepatan penurunan stunting adalah penembek. Sebagian masyarakat masih menjalankan kearifan melalui inisiatif untuk menjadi pelopor terhadap berbagai inovasi dan terobosan untuk perbaikan di masyarakat. Penembek ini terbuka terhadap ide-ide atau kegiatan baru, langsung berperan sebagai pelaku dari perubahan tersebut. Budaya terbuka terhadap ide-ide baru, dan proaktif membuat Desa Pandanwangi menjadi tempat untuk berbagai kegiatan yang dilakukan oleh pemerintah dan Lembaga swadaya masyarakat. Dukungan aktif dari masyarakat terhadap program pemerintah dan LSM membuat program bisa berjalan dengan baik, dan menjadikan Desa Pandanwangi menjadi tempat percontohan dalam berbagai kegiatan misalnya pertanian yang adaptif terhadap iklim, program perlindungan anak dan pendewasaan usia pernikahan, program kampung stunting, dan program air dan sanitasi.

Peran bonding kapital sosial dalam percepatan penurunan stunting.

1. Dukungan sosial.

Implementasi nilai dan kearifan lokal menciptakan dengan menciptakan dukungan sosial untuk percepatan penurunan stunting. Dukungan sosial di dapatkan oleh individu dan keluarga melalui serangkaian interaksi yang dilakukan dalam menjalankan nilai dan kearifan lokal. Interaksi dalam babarayan dan betanje, mendukung individu untuk mempraktekan perilaku baru yang berhubungan dengan perilaku makan sehat dan bergizi, serta keragaman makanan. Interaksi dalam implementasi nilai dan kearifan lokal menciptakan akses bagi individu untuk mendapatkan dukungan sosial untuk penurunan stunting, melalui pelatihan dan motivasi dari para penembek yang salah satunya menginisiasi perilkau hidup bersih dan sehat, dan lainnya. 
2. Pengaruh sosial.

Nilai dan kearifan lokal menciptakan pengaruh sosial yang mendukung penurunan stunting. Pengaruh terbesar adalah adanya budaya malu yang masih di pegang oleh individu dan masyarakat. Pendataan by name by address yang dilakukan oleh pemerintahan desa terhadap seluruh anak yang ada di Desa Pandanwangi telah menempatkan Desa Pandanwangi sebagai desa tertinggi angka stuntingnya. Di sisi lain, adanya informasi detail tentang tentang siapa saja anak yang masuk kategori stunting dan dari dusun mana saja mereka berasal, menimbulkan rasa risih/malu bagi keluarga dan masyarakat sekitar. Gerakan penurunan stunting kemudian dirancang oleh masyarakat bersama pemerintah untuk membantu peningkatan gizi anak-anak. Kuatnya tradisi agama dan pemuka agama juga memberi pengaruh bagi individu untuk memperkuat perilaku yang mendukung pemenuhan gizi untuk anak.

3. Akses ke sumberdaya

Kapital sosial meningkatkan akses individu terhadap sumberdaya yang berguna untuk penurunan stunting. Implementasi nilai-nilai yang terkait berbagi (betanje dan babarayan) dan kearifan lokal menciptakan akses bagi individu untuk mendapatkan sumberdaya untuk melakukan percepatan penurunan stunting. Sumberdaya yang di dapat berupa sumbedaya langsung seperti makanan, maupun sumber daya tidak langsung seperti akses terhadap informasi bantuan dari pemerintah dan LSM yang bisa di dapatkan oleh individu.

\section{Bridging Kapital Sosial dalam penurunan stunting}

Di masyarakat Pandanwangi ada beberapa kapital sosial sebagai jembatan yang menghubungkan antar individu sebagai sarana untuk percepatan penurunan stunting yaitu kerjasama dalam kelompok-kelompok dan adanya aturan desa

Berbagai jenis kelompok yang ada di masyarakat menjadi sarana perekat antar individu yang ada di desa Pandanwangi. Setiap kelompok memiliki aturan kelompok, tujuan, dan visi yang masing-masing di pegang oleh anggotanya. Dalam 
hal penanggulangan stunting, tiap kelompok berkonstribusi sesuai dengan fungsi dan tujuannya masing-masing. Ada yang berkontribusi secara langsung, ada yang tidak langsung melalui kegiatan yang mendorong adanya percepatan penurunan stunting. Kelompok PKK, Kader, dan kelompok ibu mengambil peran langsung melalui kegiatan penyuluhan, kunjungan ke rumah, penyebaran informasi tentang stunting ke keluarga, dan menghubungkan antara ibu dan fasilitas kesehatan yang ada. Kelompok lainnya seperti kelompok adat, kelompok kesenian berfungsi untuk sebagai saluran untuk penyebaran informasi melalaui kegiatan-kegiatan rutin seperti pengajian mingguan dan bulanan, acara kesenian yang ada di masyarakat, dan pertemuan rutin antar petani.

Untuk menguatkan komitmen terhadap kepedulian desa untuk mengatasi stunting secara lebih mendalam, masyarakat bersama dengan aparat desa merancang bersama peraturan-peraturan desa. Peraturan yang ada bertujuan mengatasi masalah yaitu perlindungan anak dan pendewasaan usia perkawinan yang selama ini menjadi salah satu faktor utama tingginya angka stunting. Aturan desa menyediakan juga kelembagaan yang berguna untuk membantu dan aparat desa dan masyarakat untuk monitoring pelaksanaan peraturan. Peraturan Desa juga mengamanatkan tanggungjawab dan peran seluruh stakeholder untuk implementasi seperti aparat desa, Lembaga-lembaga di masyarakat, Lembaga Pendidikan, dan yang terpenting masyarakat sendiri yang menjadi orang tua dari anak-anak.

Peran bridging kapital sosial dalam penurunan stunting adalah sebagai berikut:

1. Akses sumberdaya

Bridging kapital sosial membantu meningkatkan akses ke sumberdaya bagi individu dan kelompok untuk percepatan penurunan stunting. Keterlibatan individu dalam berbagai kelompok menciptakan akses bagi setiap anggota terhadap sumberdaya yang bisa digunakan secara langsung dan tidak langsung dalam penurunan stunting. Kelompokkelompok ibu-ibu bisa memberikan langsung berbagai kebutuhan keluarga yang memiliki anak stunting baik. Kelompok PKK dan kader posyandu dapat memberikan akses ke pemberian makanan tambahan 
bagi balita stunting yang merupakan bagian dari kegiatan Posyandu dan kegiatan PKK. Kelompok Petani juga dapat memberikan hasil pertanian dan perikanan mereka kepada anggota yang membutuhkan. Sumberdaya lain yang tidak terkait langsung misalnya bantuan alat-alat pertanian, bibit dan pupuk, yang mampu meningkatkan produktifitas pertanian anggota. Secara tidak langsung bisa meningkatkan ketahanan pangan anggota kelompok tani. Peraturan Desa juga membantu formalisasi akses ke sumberdaya. Dalam beberapa pasal di peraturan desa menekankan kewajibaan pemerintah Desa untuk mempriotritas kan anak yang stunting untuk mendapatkan bantuan atau sumbangan berupa zakat, infaq dan shadaqoh dari pemerintah atau pihak-pihak lainnya.

2. Dukungan sosial

Dukungan sosial tercipta melalui keterlibatan anggota kelompok yang memungkinkan mereka untuk saling memotivasi anggota lainnya untuk mempraktekan prilaku untuk percepatan penurunan stunting. Pemberian makanan bergizi seimbang yang di praktekkan dalam berbagai pertemuan kelompok, terutama pada kelompok ibu, membantu anggota lain untuk melakukan prilaku makan sehat tersebut di rumah. Anggota kelompok secara berkala akan membantu keluarga yang memiliki anak stunting melalui kunjungan rumah dan diskusi-diskusi pada saat pertemuan kelompok. Peraturan desa menegaskan juga bentuk dukungan sosial bagi keluarga, melalui lembaga-lembaga yang di bentuk untuk membantu mengawasi pelaksaaan peraturan. Masingmasing stakeholder di berikan tanggung jawab dan peran untuk mendukung anggota yang mengalami masalah.

3. Akses ke informasi

Keterlibatan individu dalam kelompok memberikan akses bagi mereka untuk mendapatkan informasi-informasi yang berguna untuk penurunan stunting. Anggota kelompok yang memiliki informasi tertentu bisa membagikan ke kelompok. Kelompok juga dapat memberikan akses 
informasi kepada anggota, misalnya informasi tentang stunting, cara pencegahan, cara mengatasinya dan bagaimana petunjuk praktis tentang perilaku hidup bersih dan sehat yang bisa di terapkan oleh anggota. Selain itu, informasi juga bisa terkait tentang cara mengakses bantuan dari pemerintah, dan cara mendapatkan informasi kesehatan dari puskesmas. Adanya kelompok-kelompok memungkinkan Pemerintah Desa, tokoh masyarakat, tokoh agama, petugas kesehatan untuk saling berbagi informasi dan pengetahuan kesehatan anak kepada anggota kelompok.

4. Meningkatkan ketrampilan.

Partisipasi individu dalam kelompok mampu meningkatkan ketrampilan baik individu maupun kelompok untuk mempercepat penurunan stunting. Kelompok secara rutin memberikan pelatihan kepada anggota, baik pelatihan teknis seperti kesehatan, pertanian, perikanan, maupun ketrampilan untuk peningkatan ekonomi keluarga. Peningkatan ketrampilan ini bisa terjadi dua arah. Anggota kelompok yang memiliki akses untuk mendapatkan pelatihan di tempat lain, berbagi ketrampilan dengan anggota kelompoknya. Misalnya salah satu kelompok ibu-ibu yang mendapatkan pelatihan tentang cara membuat jajanan sehat untuk balita dari salah satu program Kampung Stunting di Kabupaten, kemudian membagikan ketrampilan tersebut kepada ibu-ibu di sekitar rumah nya melalui pertemuan informal di berugak (saung). Beberapa anggota kelompok (biasanya ketua dan sekertaris) sering di undang untuk mengikuti pelatihan di kecamatan dan kabupaten, juga berbagi ke anggota kelompok.

5. Kontrol Sosial

Kapital sosial berguna sebagai kontrol sosial untuk percepatan penurunan stunting. Aturan desa yang diterapkan di desa Pandanwangi menjadi salah satu kontrol sosial yang membantu seluruh masyakarat untuk bertindak sesuai dengan yang di atur oleh peraturan Desa. Peraturan Desa tentang Perlindungan Anak membantu masyarakat 
untuk peduli terhadap anak, termasuk menjamin kebutuhan anak agar bisa tumbuh sehat dan bebas dari gizi buruk. Peraturan pendewasaan Usia Perkawinan mengatur perilaku masyarakat untuk pencegahan stunting jangka panjang. Kelompok-kelompok yang ada menjadi sarana untuk membantu penerapan aturan-aturan tersebut. Tiap kelompok juga memiliki aturan-aturan dan nilai-nilai yang dipatuhi oleh anggota. Penerapan nilai dan aturan kelompok juga merupakan bentuk kontrol sosial dari masing-masing anggota dalam kelompok. Forum Pemerhati Perempuan dan Anak misalnya menjadi yang terdepan dalam membantu sosilisasi aturan pendewasaan usai perkawinan ke masyarakat sekaligus memonitor pelaksanaannya.

6. Partisipasi Sosial.

Keberadaan kelompok dan adanya aturan desa berhasil mendorong keterlibatan masing-maisng individu dalam kelompok. Individu secara bebas bisa memiliki kelompok mana saja yang menjadi tempat mereka untuk aktualisasi diri dan bisa mendapatkan keuntungan bagi individu tersebut maupun keluarganya. Partisipasi dari individu bisa terus berkembang mengikuti perkembangan individu tersebut dalam kelompok. Misalnya individu yang dulu hanya bersifat sebagai anggota sukarela, setelah berbagai kegiatan pelatihan seperti kepemimpinan, cara berjejaring, pelatihan teknis lainnya terkait pertanian, penanganan stunting, membuat perubahan posisi menjadi "tokoh" di masyarakat. Karena adannya contoh-contoh baik tersebut, memacu individu yang lain untuk berpartispasi dalam kelompok. Partisipasi juga di dorong oleh pelibatan anggota secara menyeluruh sebagai pelaku dari kegiatan yang ada. Dalam kelompok informal misalnya, kesempatan untuk berbagi tidak hanya di dominasi oleh tokoh-tokoh saja, ataupun kader atau ketua kelompok, namun setiap anggota berksempatan untuk berbagi permasalahannya, berbagi solusi yang mereka dapatkan dari pengalaman-pengalaman mereka. 


\section{Bridging Kapital Sosial dalam Penurunan Stunting}

Linking kapital sosial di Desa Pandanwangi tercermin dari jejaring yang di bangun oleh individu dan kelompok dengan pihak luar desa. Bentuknya ada tiga yaitu bermitra dengan pemerintah kecamatan dan kabupaten, bermitra dengan Lembaga Swadaya Masyarakat, dan berjejaring dengan petani-petani di seluruh pulau Lombok.

Kemitraan dengan pemerintah baik kecamatan dan kabupaten dilakukan melalui jejaring individu dan kelompok. Individu yang ada di Desa Pandanwangi membantu menjalin network dengan pemerintah daerah melalui keterlibatan dalam sektor tertentu. Kelompok-kelompok juga berkontribusi dalam memperluas jaringan ke kecamatan dan kabupaten. PKK misalnya, mampu melakukan perluasan jaringan ke tingkat kecamatan dan kabupaten, sehingga bisa membawa program Program Cegah stunting bersama masyarakat di implemtasikan di Desa Pandanwangi. PKK melalui beberapa network, bisa mengundang beberapa pejabat untuk datang datang dan memberikan arahan dan pelatihan dalam salah satu kegiatan PKK. Melalui berhasilan implementasi program, membuat beberapa orang dari desa di undang untuk berbagi pengalaman di tingkat kecamatan, kabupaten dan provinsi. Individu yang di undang tersebut membangun jaringan baru dengan peserta-peserta pertemuan, sehingga bisa cepat mendapat informasi baru terkait program dan sumber daya lain untuk penurunan stunting.

Desa Pandanwangi juga melakukan kerjasama dengan Lembaga Swadaya Masyarakat yang berpusat di Mataram yaitu SANTAI dan KONSEPSI. Melalui kerjasama ini, mampu meningkatkan profile desa, sehingga lebih di kenal di tingkat kabupaten dan provinsi. Kepala Desa dan perwakilan kelompok, secara rutin ikut serta dalam kegiatan-kegiatan advokasi yang di lakukan oleh LSM, sehingga bisa mengakses program-program yang adai di Kabupaten dan Provinsi. KONSEPSI memiliki beberapa kegiatan yang di lakukan di Desa Pandanwangi yaitu kegiatan advokasi berbasis bukti untuk percepatan penurunan stunting, Pengurangan Resiko Bencana, dan Program Adaptasi Perubahan Iklim. Masing-masing program memiliki pendanaan yang berbeda. Setiap program yang dilaksanakan mendukung upaya pemerintah desa dan masyarakat untuk percepatan penurunan stunting baik 
melalui intervensi spesifik dan intervensi sensitive. Melalui berbagai kegiatan ini KONSEPSI mendorong penguatan komitmen desa untuk penurunan stunting, memberikan pemahaman kepada aparatur desa dan masyarakat mengenai stunting, permasalahan, dampak dan penyebabnya, dan mendorong aparatur desa untuk memprioritaskan penurunan stunting dalam kegiatan pelayanan sosial dasar masyarakat.

Melalui program PEDULI yang di gagas oleh Lembaga SANTAI, masyarakat Pandanwangi masyarakat menjalankan kegiatan yang menyasar Anak Pekerja Migran (APM). Desa Pandanwangi merupakan salah satu desa penyumbang pekerja migran terbesar di Lombok Timur. Tinggi nya angka pekerja migran ini membuat banyak anak anak di tidak bisa mendapatkan perhatian penuh dari keluarga karena ibu atau bapaknya bekerja kembali ke luar daerah dan luar negeri. Sebagai dampaknya, banyak anak yang terlantur dan tidak mendapkan pola asuh yang layak. Dampak akhirnya adalah banyak dari kelompok anak tersebut yang menderita stunting dan kasus gizi buruk lainnya. Kegiatan-kegiatanya antara lain: pelatihan, pendampingan kasus kekeasan terhadap anak, membantu untuk membuat akte kelahiran untuk anak dan akte keluarga, serta advokasi ke pemerintah kecamatan dan kabupaten untuk pendekatan layanan melalui turun langsung ke masing-masing rumah tangga, melakukan pencegahan terhadap perkawinan anak, dan membangun kerelawanan kader di masyarakat, terutama kader untuk terus aktif dan peduli terhadap berbagai permasalahan yang ada di masyarakatnya, terutama terkait anak pekeja migran dan perkawinan usia anak. Selain itu, masyarakat juga menginisasi Sekolah Perempuan. Sekolah Perempuan di bentuk sebagai tindak lanjut kepedulian kader. Kader sebelumnya menjadi tenaga sukarela untuk mengajar di PAUD Anak Pekekerja Migran (PAUD APM) yang ada Desa Pandanwangi, ikut serta dalam Sekolah Perempuan. Sekolah Perempuan melakukan pembelajaran implementasi program terkait APM dan pelatihan pengembangan ekonomi keluarga, pelatihan tentang pola pengasuhan anak, dan melakukan pendampingan kepada APM.

Desa Pandwanngi juga memiliki kelompok tani yang kuat. Untuk terus meningkatkan kemampuan pertanian dan mendapatkan informasi-informasi baru, kelompok petani di Pandanwangi berjeraring dengan petani lainnya di pulau 
Lombok. Melalui jejaring Lumbung, petani terhubung dengan 113 anggota yang berasal dari 65 kelompok tani, yang mewakili ribuan petani di NTB. Ketua jejaring Lumbung ini ada di Desa Pandwanwangi. Lumbung secara rutin melakukan kunjungan keliling ke anggota untuk saling belajar ilmu-ilmu baru terkait pertanian, dan saling mendukung untuk menuju petani yang mandiri. Selain itu, setiap tahun ada pertemuan besar yang di gelar dengan mengundang seluruh anggota untuk berbagi pengalaman dan merancang program untuk meningkatkan kemampuan petani.

Masing-masing jejaring berkontribusi secara langsung dan tidak langsung terhadap penurunan stunting. Peran dari linking kapital sosial yaitu:

1. Akses Sumberdaya

Melalui jejaring pemerintah, Desa Pandanwangi mendapatkan akses langsung terhadap sumberdaya desa dalam penurunan stunting. Melalui program sensitif misalnya Air dan sanitasi, Desa Pandanwangi mendapatkan bantuan sumur bor dari pemerintah kabupaten untuk memenuhan akses air bersih pada daerah yang kekurangan air. Untuk program stunting, Desa Pandanwangi mendapatkan bantuan PMT untuk mendukung pelaksanaan Posyandu. Desa Pandanwangi juga menjadi salah satu wilayah penurunan stunting terintegrasi, sehingga menjadi daerah prioritas bagi provinsi dan kabupaten. Kerjasama dengan LSM juga membantu Desa Pandanwangi untuk mendapatkan akes sumberdaya melalui program-porgram yang di jalankan bersama dengan masyarakat. Melalui kerjasama dengan KONSEPSI, Desa Pandanwangi mendapatkan tiga program baik aktifitas spsesifik dan sensitif stunting yang dapat di rasakan oleh masyarakat. Program advokasi penurunan stunting membantu pemerintahan desa secara langsung untuk menyusun perencanaan dan budget yang mendukung percepatan penurunan stunting. Rencana dan budget kemudian di paparkan di tingkat kabupaten, sehingga mendapat tanggapan dan bantuan program lain yang bisa mendukung desa Pandanwangi. Program yang tidak terkait langsung yaitu program pengurangan resiko bencana dan program adaptasi perubahan iklim juga 
membantu anggota yang terlibat untuk mendapatkan akses sumberdaya dan modal untuk menjalankan rencana program adaptasi untuk meningkatkan ketahanan ekonomi keluarga.

Melalui kerjasama dengan SANTAI, Desa Pandanwangi juga mendapatkan berbagai macam sumberdaya baik berupak fisik dan juga non fisik. Keberhasilan program mendapat apresiasi dari pemerintah, sehingga Pemerintah memberikan bantuan pembuatan PAUD Aanak Pekerja Migran (APM) yang menjadi sarana untuk pendidikan anak di Desa Pandanwangi. Selain itu juga mendapat bantuan ahli yang terkait APM dan Pendewasaan Usia Perkawinan (PUP) yang membantu memberikan arahan dan untuk implementasi program

2. Akses ke Informasi

Banyak nya jaringan dengan pihak luar membuat semakin terbukanya informasi baru bagi Desa Pandanwangi. Berjejaring dengan Pemerintah Kecamatan dan Kabupaten membantu Desa dalam mendapatkan informasi tentang program apa saja yang dapat di akses dari Kabupaten dan Provinsi untuk percepatan penurunan stunting. Di Kecamatan, masyarakat mendapatkan informasi tentang akses layanan kesehatan saja yang bisa di dapatkan oleh anak stunting seperti Pemberian Makanan Tambahan (PMT), kunjungan rumah oleh petugas kesehatan untuk memantau perkembangan balita, dan informasi tentang program lain yang dilakukan secara bersamasama oleh desa-desa yang ada dalam satu kecamatan. Selain akses program, aparat desa dan kelompok-kelompok juga mendapatkan informasi tentang praktek dan pembelajaran baru yang di dapatkan melalui pertemuan tingkat kecamatan dan kabupaten. Informasi bisa bersifat timbal balik. Masyarakat bisa memberikan praktik baik yang telah di jalankan di desa, sehingga bisa menjadi inspirasi bagi desa dan pemerintah untuk replikasi di tempat lain. 


\section{Peningkatan Ketrampilan}

Berjejaring dapat meningkatkan ketrampilan anggota masyarakat, kelompok maupun aparat desa. Ketrampilan yang di dapat tidak hanya terkait teknis penurunan stunting seperti pola makan gizi seimbang, pemberian ASI ekslusif, cara melakukan konseling terhadap keluarga yang memiliki anak stunting, teknik penyuluhan dan sosialisasi tentang stunting, namun juga mendapat ketrampilan dengan topik lain. Melalui kerjasama dengan SANTAI, kelompok FP2A mendapatkan pelatihan-pelatihan kepemimpinan, pelatihan tentang kesetaraan jender, hak anak, paralegal, dan cara penguatan jaringan. Selain melalui pelatihan, ketrampilan juga di dapatkan melalui coaching seperti cara melakukan pendampingan kasus kekerasan terhadap anak, dan kasus perkawinan usia anak, cara melakukan negosiasi untuk proses belas (pisah), dan cara melakukan advokasi untuk budget desa dan kabupaten.

Kerjasama dengan Lembaga KONSEPSI membantu masyarakat dan kelompok untuk memetakan potensi dan kerentanan terhadap perubahan iklim dan bencana. Kelompok juga di berikan pelatihan cara melakukan adaptasi, cara menggalang dukungan masyarakat, dan cara berjaring dengan anggota kelompok lain di luar desa, baik tingkat kecamatan, kabupaten dan provinsi. Untuk ketrampilan terkait penurunan stuning, KONSEPSI membantu memberikan ketrampilan bagi kader mengenai cara yang benar untuk pengukuran stunting, sehingga memiliki data yang valid. Selanjutanya KONSEPSI juga melatih aparat desa dan masyarakat mengenai cara membuat Rencana Anggaran Pendapatan dan Belanja Desa yang sensitif terhadap stunting. Pemerintah Desa juga dibekali ketrampilan cara mengadvokasi RAPBD ke tingkat yang lebih tinggi 
4. Akses ke Jaringan Baru

Melalui jejaring dengan Pemerintah Kabupaten, Desa juga mendapatkan informasi tentang LSM-LSM yang ada di Lombok Timur, sehingga bisa melakukan pendekatan agar bisa melakukan kegiatan di desa. Melalui kerjasama dengan KONSEPSI, Desa Pandanwangi mendapatkan akses ke banyak jejaring seperti jejaring perngurangan resiko bencana dan adaptasi perubahan iklim, berjejaring dengan desa-desa lain yang juga melakukan percepatan penurunan stuning. Melalui jejaring dengan pemerintahan, Desa Pandanwangi juga berhasil mendapatkan jejaring baru dengan Lembaga swadaya masyarakat. Sebagai contoh, pertemuan dengan Dinas Pemberdayaan Perempuan, Perlindungan Anak dan Keluarga Berencana (DP3AKB), perwakilan masyarakat Desa Pandanwangi mendapatkan informasi tentang Program Peduli yang di jalankan oleh SANTAI di Lombok Timur. Masyarakat kemudian menindaklanjuti informasi ini melalui pertemuan dengan pelaksana program yang di fasilitasi pemerintah kabupaten, sehingga pada akhirnnya program bisa di jalankan di Desa Pandanwangi. Keterlibatan Desa Pandwanwangi di Program Peduli membantu mereka berjejaring dengan desa-desa lain yang menjalankan program Anak Pekerja Migran dan Pendewasaan Usia Perkawinan.

\section{Kesimpulan}

Bentuk dan peran kapital sosial kapital sosial di Pandanwangi terbagi menjadi tiga bagian yaitu bonding, bridging dan linking kapital sosial. Bonding kapital adalah nilai-nilai yang mencerminkan budaya gotong royong (babarayan dan betanje), budaya malu dan nilai agama. Kearifan lokal yaitu embung-embung yang menjadi bagian kekerabatan komunal dan strategi ketahanan pangan, dan penembek atau pelopor. Bonding kapital berperan untuk menciptakan dan pemperkuat dukungan sosial, menciptakan pengaruh sosial, dan akses teharap sumberdaya untuk penurunan stunting. Bridging Kapital Sosial ada beberapa bentuk yaitu kejasama dalam kelompok (Kelompok PKK, Kader Posyandu, Kelompok Kesenian, Kelompok adat, Kelompok Petani, Kelompok Perkumpulan Ibu-Ibu, dan adanya 
peraturan desa yaitu Peraturan Desa Tentang Perlindungan Anak dan Peraturan Desa Pendewasaan Usai Perkawinan. Bridging kaptital sosial memberikan akses ke sumber daya, menciptakan dukungan sosial/social support, memberikan akses informasi, meningkatkan ketrampilan individu, sebagai wahana kontrol sosial, dan mendorong partisipasi sosial dari individu. Linking kapital sosial di Desa Pandanwangi dilakukan melalui berjejaring dengan pemerintah kecamatan dan kabupaten, berjejaring dengan dengan LSM yaitu Lembaga Konsepsi dan Lembaga SANTAI, dan Jejaring dengan Kelompok Petani, Lumbung. Linking kapital sosial berperan dalam memberikan akses kepada kelompok dan pemerintahan desa terkadap sumber daya, memberikan informasi terbaru terkait penurunan stunting, peningkatan ketrampilan anggota dan kelompok, serta membantu individu, kelompok dan desa dalam mendapatkan jaringan baru. Berdasarkan hasil pembahasan dan kesimpulan, peneliti menyampaikan beberapa saran tentang bagaimana kapital sosial dapat berperan lebih dalam penanganan stunting di masa yang akan datang. Saran di bagi untiuk masing-masing pihak yaitu masyarakat dan pemerintahan desa, Pemerintah Kecamatan dan kabupaten, dan LSM yang sering menjadi mitra dalam pembangunan di Indonesia

1. Pemerintah desa,

Kapital sosial merupakan modal penting yang tidak bisa di abaikan dalam menjalankan seluruh kegiatan di masyarakat. Dalam upaya penuruan stunting, pemetaan kapital sosial perlu di lakukan secara berkala, minimal setahun sekali pada saat pembuatan rencana kerja desa dan penyusunan Rencana Anggaran dan Belanja Desa. Kegiatan desa yang terkait stunting, dapat menggunakan kapital sosial sebagai saluran untuk implementasi program

2. Bagi Pemerintah Kabupaten dan Kecamatan.

Pemerintah Kabupaten dan Kecamatan perlu mengadakan analisa sosial partisipatif bersama masyarakat di desa sebelum implementasi program. Analisa sosial, termasuk melakukan pemetaan kapital sosial yang ada penting agar tidak ada tumpang tindih dalam implementasi program. Pemerintah Daerah bisa menggunakan kelompok-kelompok yang sudah ada di masyrakat untuk menjalankan program, sehingga tidak perlu menciptakan kelompok baru 
untuk menjalankan program. Nilai-nilai dan kearifan lokal yang ada, apabila digunakan dengan baik, bisa membantu percepatan pencapaian program. Pemerintah Kabupaten perlu memperluas jaringan pemerintah desa melalui berbagai kegiatan di tingkat kabupaten, dan membantu menghubungkan antara pemerintah desa dengan Lembaga swadaya masyarkat

3. Bagi Lembaga Swadaya Masyarat

Lembaga Swadaya Masyarakat penting untuk melakukan identifikasi kapital sosial di masyarakat dan menggunakannya untuk proses pengembangan masyarakat. Kapital sosial baik bonding, bridging, dan linking dapat membantu percepatan pembangunan di desa. Analisa sosial partisipatif perlu di lakukan di awal, kemudian membuat perencanaan partisipatif bersama dengan masyarakat untuk merencanakan bagaimana menggunakan kapital sosial yang ada untuk meningkatkan kesejahteraan masyarakat. Masyarakat dan pemerintahan desa juga harus di dorong dan di fasiltasi dalam mengembangkan jaringan, baik jaringan antar masyarakat, maupun jaringan antara desa yang memiliki kesamaan program.

\section{Daftar Pustaka}

Adi, Isbandi Rukminto. 2013. Intervensi Komunitas: Pengembangan Masyarakat sebagai Upaya Pemberdayaan Masyarakat. Jakarta: Rajawali Pers

Black, Robert E, et al. 2013. Maternal and Child undernurition and overweight in low income and middle-income. Countries, Maternal and Child Nutrition Series, 382(9890), 427-451

Claridge, Tristan. 2018. Functions Of Social Capital - Bonding, Bridging, Linking Social. Social Capital Research

Creswell, J. W. 2015. Penelitian Kualitatif \& Desain Riset: Memilih diantara Lima Pendekatan (edisi ke 3). London: Sage Publication

Eriksson, Malin. 2011. Social Capital and Health: Implications For Health Promotion. Global Health Action. 4 (5611)

Galab, Shaik, et all. 2016. Exploring Linkages Between Maternal Social Capital And Children's Nutritional Status In Andhra Pradesh. Young Lives

Grootaert, C. 1998. Social Capital: The Missing Link? Sosial Capital Initiative. Working Paper No.3 Commission on Growth and Development

Ife, Jim. 2013. Community Development in an Uncertain World: Vision, Analysis and Practice. New York: Cambridge University Press. 
Bentuk dan Peran Kapital Sosial dalam Percepatan Penurunan Stunting

di Desa Pandanwangi, Lombok Timur

Midgley, James. 1995. Social Development: The Development Perspective In Social Welfare. California: Sage Publication.

Minot, Nicholas, Samson Dejene, Rachel Huang. 2019. Food and nutrition security in East Lombok. International Food Policy Research Institute.

Taqiuddin, Moh. 2017. Struktur Sosial dalam proses perubahan, Implikasi Pembelajaran Agrometeorologi dalam 'Warung Ilmiah Lapangan' Pada Dinamika Struktur Sosial Petani Sawah Tadah Hujan di Pulau Lombok. Program Studi Pasca Sarjana Sosiologi Fakultas Ilmu Sosial dan Ilmu Politik Universitas Indonesia

Woolcock, M. 1998. Social Capital and Economic Development: Toward A Theoretical Synthesis and Policy Framework. Theory and Society, 27(2), 151-208.

Woolcock, M., \& Narayan, D. 2000. Social Capital: Implications for Development Theory, Research, and Policy. The World Bank Research Observer, 15(2), $225-249$.

Zakaria, Liez. 2018. Studi Kebijakan dan Program Ketahanan Pangan dan Gizi di Nusa Tenggara Barat dan Nusa Tenggara Timur. Frontiers for Health (Yayasan Cakrawala Kesehatan) \& SNV Indonesia

Vol. 3 No. 2 Desember 2021 p-ISSN: 2685-7626 e-ISSN: 2714-7614| 251 